\title{
Psychological ownership: Development of an instrument
}

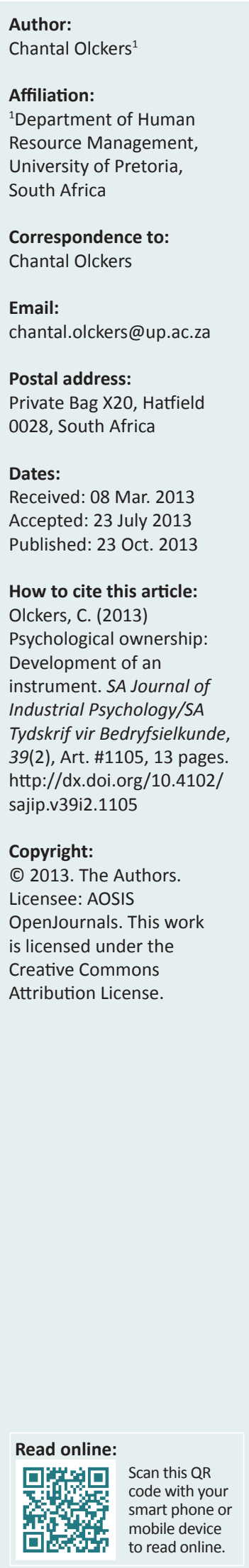

Orientation: Psychological ownership emerged recently as a positive psychological resource that could be measured and developed and that could affect the performance of organisations.

Purpose: The purpose of this study was to develop an instrument to measure psychological ownership in a South African context.

Motivation for the study: It was found that previous instruments for the measurement of psychological ownership lacked the ability to grasp the extensive reach of psychological ownership.

Research design, approach and method: A quantitative cross-sectional survey was conducted on a non-probability convenience sample of 713 skilled, highly-skilled and professional employees from various organisations in both the private and public sectors in South Africa.

Main findings: Although a 69-item measurement instrument was developed in order to capture the proposed seven-dimensional psychological ownership construct, it became evident when analysing the data that a four-factor model comprising 35 items was suitable.

Practical/managerial implications: If a sense of psychological ownership toward an organisation could be established amongst its employees by addressing the factors as measured by the South African Psychological Ownership Questionnaire, organisations could become enhanced workplaces and, as a result, sustainable performance could be promoted and staff could be retained.

Contribution/value-add: The instrument for measuring psychological ownership in a South African context could serve as a diagnostic tool that would allow human resource professionals and managers to determine employees' sense of psychological ownership regarding their organisation and to focus specifically on weak dimensional areas that could be improved.

\section{Introduction}

\section{Problem statement \\ Key focus of the study}

What is wrong with you? This question has long been the dominant mantra of Psychology. However, positive psychologists (Peterson, 2000; Seligman, 1999; Snyder, 2000) have urged other psychologists to focus rather on what is right with people than on what is wrong with them. Luthans (2002) explored the implications of positive psychology for organisational behaviour and advised all researchers in the domain of Psychology to adopt a proactive positive organisational behavioural approach.

Psychological ownership has recently emerged as a positive psychological resource and it meets the recognised positive organisational behaviour (POB) criteria because it is based on theory and research, can be measured, is open to change and development and affects the performance of organisations (Avey, Avolio, Crossley \& Luthans, 2009). However, instruments that have been used in an attempt to measure the psychological ownership phenomenon have lacked evidence in support of the extensive reach of psychological ownership.

\section{Background to the study}

When psychological and work-related constructs are measured in a cross-cultural framework, it is essential to establish equivalence of the measures prior to drawing significant substantive conclusions about the relative value of constructs across countries (De Beuckelaer, Lievens \& Swinnen, 2007). Several studies undertaken in South Africa have indicated that because of national cultural differences, the reliability and validity of instruments developed in other countries cannot simply be generalised for South Africa and thus have limited practical value for South African cross-validation purposes. Examples are Litwin and Stringer's Organisational 
Climate Questionnaire (Olckers, Buys \& Zeeman, 2007), the multi-dimensional Emotional Empathy scale (Olckers, Buys \& Grobler, 2010) and the Organisational Culture Profile questionnaire (Maré, 2009).

\section{Trends from the research literature}

Two measuring instruments are available for measuring the psychological ownership phenomenon. Pierce, Van Dyne and Cummings (as cited in Vandewalle, Van Dyne \& Kostova, 1995) have developed and validated a five-item instrument for the measurement of psychological ownership. According to them, psychological ownership is operationalised with a set of items measuring the attitude of feeling ownership of the organisation, for example, 'this is MY organisation' and 'I sense that this organisation is OUR company'. The coefficient alpha of Cronbach, established in three different US samples, has shown acceptable internal consistency reliability $(0.87,0.90$ and 0.93$)$. A limitation of this instrument is that psychological ownership is measured by utilising only a five-item instrument. Since psychological ownership is a multi-dimensional construct (Avey et al., 2009), this five-item instrument seemingly lacks the ability to grasp the extensive reach of psychological ownership.

Avey et al. (2009) have developed a 16-item, five-dimensional measure of psychological ownership and have distinguished between two forms of psychological ownership: promotionorientated and prevention-orientated psychological ownership. Their basis for examining these two unique and independent forms of psychological ownership is based on Higgens' (1997) regulatory focus theory. According to Higgens (1997), people have two basic self-regulation systems. The one system regulates the achievement of rewards and focuses individuals on promotion goals, whereas the other system regulates the avoidance of punishment and focuses individuals on prevention goals. Promotion goals include wishes, hopes and aspirations, representing the 'ideal self'. Prevention goals include obligations, duties and responsibilities, representing the 'ought self'. Both prevention and promotion goals are important for the survival of the human being and the one approach is not necessarily more desirable than the other. In certain contexts the promotion focus is necessary in order to pursue development and improvement, whereas in other contexts a more preventive focus is needed if individuals seek to ensure safety, stability and predictability (Higgens, 1997). According to Avey et al. (2009), individuals who are more promotion orientated might experience quite different feelings toward targets of ownership compared with those individuals who are prevention orientated.

According to Avey et al. (2009), promotion-orientated psychological ownership consists of four theory-driven components: self-efficacy; a sense of belonging; self-identity with the target; and accountability. Territoriality has been identified as being the only dimension of a preventive form of psychological ownership. Avey et al. (2009) have admitted that a limitation of their instrument might be the comprehensiveness of the dimensions that represent psychological ownership; they have incorporated only dimensions that previous theoretical contributions linked directly to feelings of psychological ownership. With this caveat, Avey et al. (2009) recommend that future theory building and research be done that might demonstrate a link between psychological ownership and other related concepts.

\section{Research purpose}

The purpose of this study was to develop an instrument for measuring psychological ownership in a South African context since previous studies (Avey et al., 2009; Pierce, Kostova \& Dirks, 2001) have not succeeded in developing a comprehensive measurement instrument.

\section{Potential value added by the study}

The instrument could serve as a diagnostic tool that would allow human resource professionals and managers to profile employees' psychological ownership regarding their organisation and to focus specifically on improving those dimensional areas that are weak and in need of attention. Previous research by Olckers and Du Plessis (2012b) has indicated that improvement of psychological ownership can positively assist organisations in retaining talent and influencing the intentions of skilled employees to remain with their organisations.

\section{Literature review Definition of psychological ownership}

Pierce et al. (2001) define psychological ownership as a cognitive-affective construct that is based on individuals' feelings of possessiveness and of being psychologically tied or attached to objects that are material and immaterial in nature. Psychological ownership asks the question, 'How much do I feel this organisation is mine?' (Van Dyne \& Pierce, 2004, p. 443).

\section{Dimensions of psychological ownership}

Originally, Pierce et al. (2001) based their psychological ownership construct on the three dimensions of selfefficacy, self-identity and belongingness. Avey et al. (2009) have expanded on the development of this construct by categorising the dimensions of psychological ownership as either promotion- or prevention-orientated and by positing the concepts of territoriality and accountability as additional dimensions of psychological ownership. Having built on the theoretical model of Avey et al. (2009) and having reviewed the literature extensively, Olckers and Du Plessis (2012a) have suggested that autonomy and responsibility should be included as possible additional dimensions of psychological ownership. Therefore, according to Olckers and Du Plessis (2012a), psychological ownership is a multi-dimensional construct that comprises seven dimensions that impact the extent to which psychological ownership is experienced. The multi-dimensional construct of psychological ownership and its proposed dimensions are displayed in Figure 1 and will be discussed in more detail. 
Promotion-orientated psychological ownership: Six promotionorientated psychological ownership dimensions have been identified: self-efficacy, self-identity belongingness, accountability, autonomy and responsibility (Avey et al., 2009; Olckers \& Du Plessis, 2012a; Pierce et al., 2001).

Self-efficacy: Self-efficacy constitutes individuals' beliefs in their personal ability to accomplish tasks (Bandura, 1995) and has also been referred to as confidence (Avey et al., 2009). According to Furby (1978), being in control forms an important part of self-efficacy. Therefore, the possibility of being in control and being able to effect a desirable outcome of actions is a psychological component that results in feelings of self-efficacy and in the promotion of psychological ownership.

Self-identity: According to Dittmar (1992), self-identity refers to a personal cognitive connection between an individual and an object or target (for example the organisation) and reflects the individual's perception of oneness with the target (Porteous, 1976). The object or target of possession is thus seen by individuals as an extension of who they are (Avey et al., 2009). Interaction with their possessions provides people with comfort, autonomy, pleasure and opportunity, all of which facilitate the development and cultivation of their identity (Kron \& Saunders, as cited in Pierce, Kostova \& Dirks, 2003). The motivation for psychological ownership is thus, in part, grounded in self-identity.

Belongingness: Individuals have a need to have a certain personal area or space - 'a home' - in which to dwell that satisfies the pressing psychological need to belong (Weil, 1952). According to Pierce et al. (2001), feelings of psychological ownership through attachment to a place or an object lead to that place or object becoming 'home' to the individual. Belongingness in terms of psychological

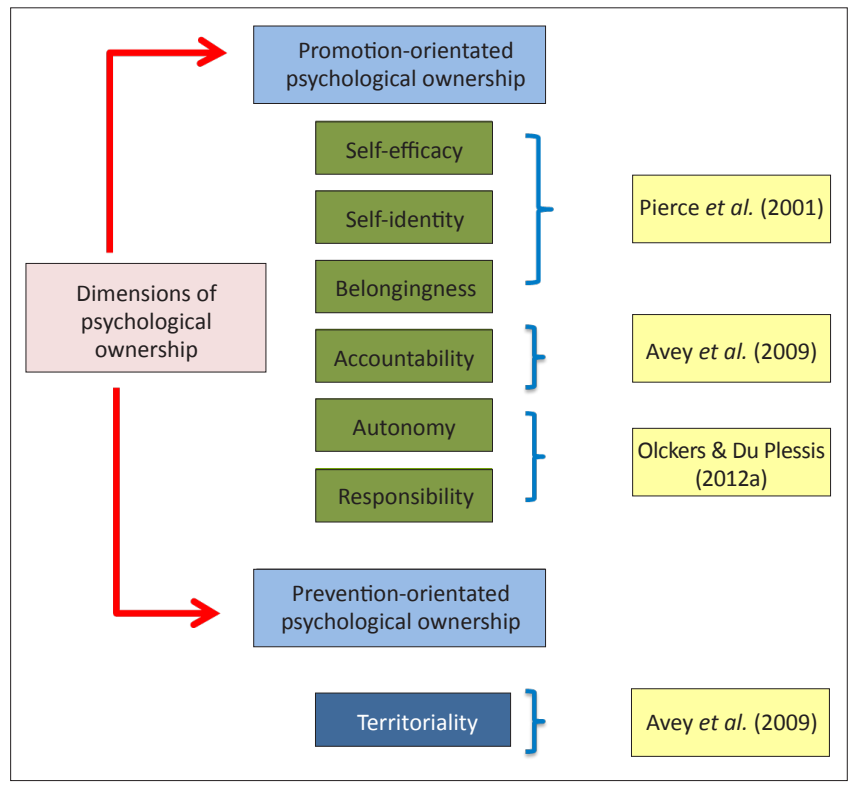

Source: Olckers, C., \& Du Plessis, Y. (2012a). Psychological ownership: A managerial construct for talent retention and organisational effectiveness. African Journal of Business Management, 6(7), 2585-2596

FIGURE 1: Theoretical dimensions of psychological ownership. ownership in organisations refers to the extent to which individuals feel 'at home' in their work place (Porteous, 1976). Avey et al. (2009) state that employees who experience a sense of ownership at work are more positive and report that they occupy a place in the organisational context where they belong. The need of the individual to belong in their place of work can be satisfied by a particular job, work team, division or even an organisation as a whole (Avey et al., 2009).

Accountability: Accountability is defined as the implicit or explicit expectation of the perceived right to hold others and oneself accountable for influences on one's target of ownership (Lerner \& Tetlock, 1999). Accountability has to do with accepting responsibility and demonstrating transparency and answerability voluntarily (Wood \& Winston, 2007). According to Pierce et al. (2001), individuals who experience increased feelings of psychological ownership will act as the conscience of others and will call others to account for influences on their target of ownership.

Autonomy: Ryan and Deci (2006) define autonomy as the regulation of the self and the extent to which a person needs or is eager to experience individual initiative in performing in the organisation. The ability to exercise influence and control over objects forms an important aspect of possession and ownership (Rudmin \& Berry, 1987). Amabile (1983) and Utman (1997) are of the opinion that the promotion of autonomy frees individuals to experience attachment and intimacy. Mayhew, Ashkanasy, Bramble and Gardner (2007) provide evidence that if employees are empowered and allowed to exercise control over important aspects of their work arrangements, the manifestation of work-related attitudes (job satisfaction and organisation-based selfesteem) and other behaviours which improve their sense of ownership are promoted.

Responsibility: Feelings of ownership are accompanied by a felt responsibility for the target of ownership and the implicit right to control associated with ownership also leads to a sense of responsibility (Pierce et al., 2001). Pierce et al. (2001) further state that when the individual's self is closely linked to the organisation, as in the case of psychological ownership, a desire to maintain, enhance and protect that identity will result in an enhanced sense of responsibility for the target of these ownership feelings. According to Rogers and Freundlich (1998), employees who feel like owners of the organisation believe that they have the right to influence the direction of the organisation and that they have a greater responsibility than those who do not feel ownership.

Prevention-orientated psychological ownership: Preventionorientated psychological ownership is characterised by only one dimension, namely that of territoriality.

Territoriality: Brown, Lawrence and Robinson (2005, p. 580) suggest that: 'the stronger an individual's psychological ownership of an object, the greater the likelihood he or she will engage in territorial behaviour toward that object'. According to Avey et al. (2009), territoriality might lead 
to people becoming too preoccupied with the 'objects of ownership', with the result being that they might not want to share the object (for example, machinery or physical space). This happens at the expense of their performance or other pro-social behaviours. However, despite these potentially negative outcomes, it is possible that feelings of territoriality might promote positive organisation outcomes. Avey et al. (2009) illustrate this by means of the following example:

[I]f the individual's work is less team-based and more based on being an individual contributor, for example, a sales agent who 'owns a particular territory', then a territorial orientation may lead to positive outcomes. (p. 176)

Therefore, territorial psychological ownership might have positive consequences despite its having a typically negative connotation.

\section{Consequences of psychological ownership}

Pierce, Rubenfeld and Morgan (1991) have theorised that psychological ownership can be associated with positive behavioural and psychological consequences and that these associations will hold regardless of the organisational member's financial ownership and the member's legal status as owner or non-owner. Promotion-orientated psychological ownership has been associated with: greater commitment to the organisation (Vandewalle et al., 1995); greater accountability (Vandewalle et al., 1995); greater job satisfaction (Avey et al., 2009; Buchko, 1993; Mayhew et al., 2007; Van Dyne \& Pierce, 2004); better organisational performance (Van Dyne \& Pierce, 2004; Wagner, Parker \& Christianson, 2003); better organisation-based self-esteem (Avey et al., 2009; Vandewalle et al., 1995; Van Dyne \& Pierce, 2004); organisational citizenship behaviours (Avey et al., 2009; Vandewalle et al., 1995; Van Dyne \& Pierce, 2004); improved extra-role behaviour (Vandewalle et al., 1995); and the intention to stay in the organisation (Avey et al., 2009; Buchko, 1993). Other outcomes of psychological ownership are stewardship, promotion of organisation change, personal risk-taking, self-sacrifice and caring and protective behaviours directed toward the target of ownership (Dirks, Cummings \& Pierce, 1996; Pierce et al., 2001).

Unfortunately, according to Pierce et al. (2001), psychological ownership might be detrimental to the reaching of organisational goals in certain circumstances. Possessive employees might, for instance, hold onto authority to the extent of refusing to delegate and share information; obstruct moves towards participative teamwork and cooperation; or even employ sabotage or show other deviant behaviour.

This study focused on the positive aspects of psychological ownership; however, there is a 'dark side' to psychological ownership. In this study, a negative side of psychological ownership, namely territoriality, was acknowledged as being a preventive form of psychological ownership.

\section{Research design}

In this study, an instrument for measuring psychological ownership was developed by following a combination of steps as suggested by DeVellis (2003) and Hinkin (1998).

\section{Research approach}

A cross-sectional design was chosen within the nonexperimental design. A cross-sectional method is usually employed for descriptive studies. The advantage of a crosssectional design is that it is less costly and time consuming than a longitudinal design.

\section{Research method}

The development of the South African Psychological Ownership Questionnaire (SAPOS) was conducted in two phases - the scale development and pilot study phase and the item evaluation phase.

\section{Phase 1: Scale development and pilot study}

During Phase 1, the constructs comprising psychological ownership were defined and items were generated for each of the constructs. These items were reviewed by a panel of experts and piloted.

Scale development: By following a deductive approach (Hinkin, 1998), items were generated for each one of the seven dimensions, namely self-efficacy, self-identity, belongingness, accountability, responsibility, autonomy and territoriality. The guideline of Harvey, Billings and Nilan (1985) was followed with the ultimate goal of retaining at least four to six items per dimension in order to ensure the homogeneity of items within each latent construct.

A total number of 54 items representing the seven theory-driven dimensions of psychological ownership were generated. The numbers of items representing the dimensions are indicated in Table 1. A panel of nine subject experts reviewed the initial pool of items to judge each item related to the specific dimension of psychological ownership. The experts commented on the item content, item style and comprehensiveness of the instrument. The quasi-quantitative approach to content validity by Lawshe (1975) was used to facilitate the retention, revision or rejection of specific items. The Content Validity Ratio (CVR) for each item was computed by making use of the following formula:

$\mathrm{CVR}=\frac{n e-\frac{N}{2}}{\frac{N}{2}}$

[Eqn 1]

Where: $n e=$ number of subject matter experts who indicated the item as essential; and $N=$ the total number of subject matter experts on the panel.

The minimum CVR value, according to the panel size ( $N=$ 9), for an item to be retained as part of the content validity testing (Lawshe, 1975) was 0.78. All items with a CVR value of less than 0.78 should therefore be rejected. Out of the original 54 items, 20 should have been rejected because their CVR values were less than 0.78 . Table 1 gives a summary of the original number of items compared with the number of items retained after the application of the Lawshe (1975) technique. 
However, 11 of the 20 items were retained, despite the Lawshe application, for the following reasons: Although three items (one item from each one of the following dimensions: selfefficacy, self-identity and accountability) had CVR values of less than 0.78 , it was decided to retain these three items since seven of the nine experts indicated that these items were unclear and that if the questions could be rephrased, they could be retained. Rejection of eight territoriality items could be as a result of the fact that the experts experienced territoriality as negative and as a potential threat to psychological ownership. The researcher purposefully did not disclose to the experts that territoriality was a preventive form of psychological ownership. Their response to these items confirmed the researcher's view that territoriality is a preventive form of psychological ownership. In their study, Brown et al. (2005, p. 580) focus on the territoriality concept as being behavioural and they propose that 'the stronger an individual's psychological ownership of an object, the greater the likelihood he or she will engage in territorial behaviours'. Although Pierce et al. (2001) argue that psychological ownership is a cognitive-affective construct, Avey et al. (2009) focus heavily on the cognitive aspects (versus behavioural displays) of territoriality as a preventive form of psychological ownership. This also applies to this study. Although territoriality might lead people to become too preoccupied with their 'objects of ownership' at the expense of their performance or other pro-social behaviours (Avey et al., 2009), the possibility exists that feelings of territoriality might promote positive organisational outcomes. If individuals believe that by protecting their territory they are doing what is right (Altman, as cited in Avey et al., 2009), territoriality might lead to increased retention and performance. Scholars such as Porteous (1976) have suggested that individuals exercise control by the 'marking' of objects, which contributes to their attachment to the object and the psychological ownership experienced.

TABLE 1: Comparison between the original number of items and items retained after the application of the Lawshe technique.

\begin{tabular}{lll}
\hline Dimension & Original number of items & Items retained \\
\hline Self-efficacy & 7 & 5 \\
Self-identity & 8 & 7 \\
Belonging & 7 & 4 \\
Accountability & 6 & 3 \\
Territoriality & 9 & 1 \\
Autonomy & 10 & 8 \\
Responsibility & 7 & 6 \\
\hline Total & $\mathbf{5 4}$ & $\mathbf{3 4}$ \\
\hline
\end{tabular}

This type of behaviour might cause individuals to feel more secure and 'at home' and they might feel that they discover themselves in the marked object. This study supports the viewpoint of Avey et al. (2009) that territorial psychological ownership with its typically negative implications might have a positive side. Therefore, the researcher decided to retain the originally-rejected eight items which represented the territoriality dimension.

However, in judging the entire construct as a possible measure, the experts suggested that additional items should be added to all the dimensions underpinning psychological ownership except for the territoriality dimension, since the inclusion of additional items would increase the likelihood that a factor analysis would reflect accurately the true underlying structure of the item pool. Therefore, in the second round of items derived from the literature study, 24 additional items as per Table 2 were added to each dimension in order to better represent the total content domain, resulting in 69 items. Table 2 indicates the number of items to be included in the final instrument after applying the Lawshe technique and then adding additional items.

Five of the original nine experts served as a second set of expert judges for content validation of the 69 items and agreed that all 69 items be included in the final construct measure of psychological ownership. The 69 items were measured on a six-point, Likert-type scale which anchored on 1 = strongly disagree and $6=$ strongly agree.

Pilot study: A pilot study was initiated. Paper copies of the questionnaire comprising 69 items were distributed to a small group of individuals $(n=46)$ from the same population as the eventual project's target population. Although the pilot sample was small, conducting the pilot study assisted in identifying ambiguous or unclear items and facilitating completion of the final questionnaire (Welman, Kruger \& Mitchell, 2005). Several respondents expressed confusion regarding the meaning of the words 'own up to' used in two of the items. As a result, the wording was changed, as is indicated in Table 3.

\section{Phase 2: Item evaluation}

Following the development of the scale and the pilot study, the 69-item psychological ownership scale was administered and evaluated using a development sample.

TABLE 2: Number of items included in the final instrument after adding additional items.

\begin{tabular}{|c|c|c|c|c|}
\hline Dimension & $\begin{array}{l}\text { Number of items retained after the } \\
\text { application of the Lawshe technique }\end{array}$ & $\begin{array}{l}\text { Number of items kept despite the } \\
\text { Lawshe application }\end{array}$ & $\begin{array}{l}\text { Second round of items derived from } \\
\text { literature study }\end{array}$ & $\begin{array}{l}\text { Total number of items to be } \\
\text { included in the final instrument } \\
\text { to be tested }\end{array}$ \\
\hline Self-efficacy & 5 & 1 & 4 & 10 \\
\hline Belonging & 4 & - & 5 & 9 \\
\hline Accountability & 3 & 1 & 6 & 10 \\
\hline Territoriality & 1 & 8 & - & 9 \\
\hline Responsibility & 6 & - & 3 & 9 \\
\hline Total & 34 & 11 & 24 & 69 \\
\hline
\end{tabular}




\section{Participants}

The target population from which the sampling frame was chosen for this study consisted of a diverse group of professional, highly-skilled and skilled individuals employed in both the private and public sectors. The reason for choosing employed individuals was that psychological ownership toward an organisation can only develop in individuals who are employed; and the research objective for the proposed study was to develop an instrument to measure psychological ownership. Mattes and Richmond (2000) have defined skilled, highly-skilled and professional employees as follows: a skilled employee is one who possesses some special skill, knowledge or ability to perform his or her work. A skilled worker might have attended a university, college or technical school, or might have learned the skills on the job. A highly-skilled worker is a worker who is capable of working efficiently, exercising substantial independent judgement, carrying out duties with responsibility and (usually) supervising efficiently the work of skilled employees. A professional is an individual who typically possesses a large body of knowledge derived from extensive, specialised educational training (usually tertiary), earns a comfortable salary, exercises some level of autonomy in the workplace, is frequently engaged in challenging work that is intellectual and creative and is expected to exercise independent judgement and professional ethics in carrying out his or her responsibilities. Various organisations within the private and public sectors were approached with a view to gathering data from a diverse base. The criteria set for the suitability of an organisation were that it had to have a diverse workforce employed in a broad range of occupations and that the employees had to have access to electronic mail.

A non-probability sample of 713 was collected from professional, highly-skilled and skilled employees in various organisations in both the private and public sectors in South Africa. Detailed information about the demographic characteristics of the sample is presented in Table 4.

The sample comprised $40.59 \%$ men and $49.41 \%$ women. The majority of the sample (59.54\%) comprised White people. Of the respondents, almost $63 \%$ were between 30 and 49 years of age. Approximately $90 \%$ of the sample had obtained a tertiary education. In the sample, $68 \%$ of the respondents functioned on a managerial level. Of the sample respondents, $43.67 \%$ had been working in their current organisation for a

TABLE 3: Original versus revised items identified from the pilot study.

\begin{tabular}{ll}
\hline Original item & Revised item \\
\hline l own up to my mistakes in the organisation. & I acknowledge my mistakes in the organisation. \\
l own up to the consequences of my decisions in the organisation. & I accept the consequences of my decisions in the organisation. \\
\hline
\end{tabular}

TABLE 4: Demographic information on the respondents.

\begin{tabular}{|c|c|c|c|c|}
\hline Variable & Category & $f$ & $\%$ & Cumulative $\%$ \\
\hline \multirow[t]{4}{*}{ Gender } & Male & 287 & 40.59 & 40.59 \\
\hline & Female & 420 & 49.41 & 100 \\
\hline & Total & 707 & - & - \\
\hline & Omitted data & 5 & - & - \\
\hline \multirow[t]{5}{*}{ Ethnic group } & African & 226 & 32.19 & 32.19 \\
\hline & Mixed-race & 24 & 3.42 & 35.61 \\
\hline & Indian & 34 & 4.84 & 40.45 \\
\hline & Total & 702 & - & - \\
\hline & Omitted data & 10 & - & - \\
\hline \multirow[t]{5}{*}{ Age } & Younger than 29 & 137 & 19.2 & 19.1 \\
\hline & $30-39$ & 213 & 28.87 & 49.07 \\
\hline & $40-49$ & 240 & 33.66 & 82.73 \\
\hline & $50+$ & 122 & 17.13 & 100 \\
\hline & Total & 712 & - & - \\
\hline \multirow{5}{*}{ Education } & Diploma & 223 & 31.95 & 40.55 \\
\hline & Bachelor's degree & 135 & 19.34 & 59.89 \\
\hline & Postgraduate degree & 280 & 40.11 & 100 \\
\hline & Total & 698 & - & - \\
\hline & Omitted data & 14 & - & - \\
\hline \multirow[t]{6}{*}{ Operating level in organisation } & Operational level & 221 & 31.94 & 31.94 \\
\hline & Junior management & 150 & 21.68 & 53.62 \\
\hline & Middle management & 201 & 29.05 & 82.66 \\
\hline & Senior management level & 120 & 17.34 & 100 \\
\hline & Total & 692 & - & - \\
\hline & Omitted data & 20 & - & - \\
\hline \multirow[t]{4}{*}{ Years working in current organisation } & Less than 5 years & 307 & 43.67 & 43.67 \\
\hline & $6-10$ years & 138 & 19.35 & 63.02 \\
\hline & $11-20$ years & 163 & 22.44 & 85.46 \\
\hline & $21+$ years & 104 & 14.61 & 100 \\
\hline
\end{tabular}


period of less than five years and the remainder (66.33\%) had been employed for more than five years.

\section{Procedure}

Prior to the study, the necessary permission to conduct the research was obtained from the authorities. Several organisations were approached to take part in the research and informed consent for participation in the research study was obtained. The purpose of the research was explained clearly to the respondents. Participation in the survey was voluntary and informed consent was obtained from the respondents. Data were collected by means of an electronic self-administered questionnaire; in some cases hard copies were distributed. The confidentiality and anonymity of the respondents were respected at all times.

\section{Statistical analysis}

To validate the underlying structure of the instrument, a combination of exploratory factor analysis (EFA) and confirmatory factor analysis (CFA) was performed.

The sample was split randomly into two groups. The first group was used to identify the underlying structure of the construct and the second group to validate the structure (Krzystofiak, Cardy \& Newman, 1988). According to the requirements set by Worthington and Whittaker (2006), the sample size was sufficient for conducting a factor analysis.

For the purpose of identifying the underlying structure of the instrument, an EFA was performed on the sample comprising 357 individuals. Before the commencement of the EFA, the factorability of the correlation matrix was determined by applying the Bartlett Test of Sphericity and the Kaiser-Meyer-Olkin measure of sampling adequacy (KMO). In the EFA, the responses on the 69 items of the instrument were correlated and rotated using maximumlikelihood factor extraction with oblique rotation with SPSS (version 16) statistical software (SPSS Inc., 2008). An oblique rotation was used because the factors were assumed to be correlated conceptually (Worthington \& Whittaker, 2006). Horn's parallel analysis (1965) was used to determine the number of factors that would be considered suitable for further retention. For the purpose of creating a parsimonious and simple structure, all factor loadings of less than 0.4 in the rotated pattern matrix and items that cross-loaded were removed (Hair, Black, Babin, Anderson \& Tatham, 2006). Items that loaded clearly on a single appropriate factor, based on theoretical grounds, were retained (Worthington \& Whittaker, 2006). A second-order factor analysis was performed using maximum-likelihood factor extraction with an oblique rotation to explore the hierarchical nature of the scale.

To validate the underlying structure, the psychological ownership measure was subjected to CFA on the other half of the sample $(n=356)$. The EQS (version 6.1) structural equation modelling software was employed for executing the CFA (Bentler, 2004). Assumptions about the normality of the data were assessed using Mardia's normalised estimates. According to Bentler (2007), Mardia's normalised estimate values of greater than 5.00 indicate that the data is nonnormally distributed. Tabachnick and Fidell (2007) suggest that, in the case of non-normality, the robust maximumlikelihood estimate with the Satorra-Bentler scaled chisquare and the adjustment of the standard errors should be employed. Bentler (2007) proposed that the standardised root mean square residual (SRMR) should be reported, accompanied by at most two other indices of fit, such as the comparative fit index (CFI).

Descriptive statistics, including the mean, standard deviation, kurtosis and skewness, were computed. Evidence of internal consistency was calculated using the coefficient alpha of Cronbach. Hair et al. (2006) recommend that items with an alpha correlation of 0.70 and higher are viewed as acceptable.

Evidence of criterion-related validity was provided by examining the relationship between psychological ownership and organisational commitment, job satisfaction and turnover intentions. Organisational commitment, job satisfaction and turnover intentions are recognised consequences of psychological ownership (Avey et al., 2009; Mayhew et al., 2007; Van Dyne \& Pierce, 2004) According to Cronbach and Meehl (1955), the relationship between the focal construct (psychological ownership) and similar constructs should be examined in order to develop a nomological network.

To assess organisational commitment, all eight items from the Affective Organisational Commitment Scale of Meyer and Allen (1991) were used. Vandewalle et al. (1995) and Van Dyne and Pierce (2004) have shown that affective commitment is related to psychological ownership. The eight items were measured on a seven-point scale, ranging from 1 = strongly disagree to 7 = strongly agree. Meyer and Allen (1991) have found a coefficient alpha of 0.87 for the affective commitment scale. In this study, the affective commitment scale yielded an acceptable reliability alpha $(\alpha=0.71)$.

Job satisfaction was measured using all three items from the job satisfaction scale that forms part of the job diagnostic survey of Hackman and Oldham (1980). Although Idaszak, Bottom \& Drasgow (1988) suggest that an instrument should have at least four to six items per scale, Tabachnick and Fidell (2007) suggest retaining at least three items per factor. The three items were measured on a seven-point scale, ranging from 1 = disagree strongly to 7 = agree strongly. This scale demonstrated internal reliability of 0.65 .

Turnover intentions were assessed by using a three-item turnover-intention scale used by O'Driscoll and Beehr (1994). The three items rated whether respondents thought about leaving their job, planned to look for a new job over the next 12 months, or would actively search for a new job outside the organisation. O'Driscoll and Beehr (1994) obtained an alpha of 0.93 from the three-item turnover intention scale in their study. The three items were measured on a six-point rating scale. The coefficient alpha of Cronbach for turnover intentions was 0.77 . 


\section{Results}

The results of the EFA, CFA and criteria-related correlation statistics will be discussed in this section.

\section{Exploratory factor analysis}

A statistically-significant Bartlett's Test of Sphericity ( $p<$ 0.001 ) and a KMO measure of sample adequacy of 0.931 , which were well above the guideline of 0.60 (Tabachnick \& Fidell, 2007), confirmed that the overall significance of the correlations within the correlation matrix was suitable for factor analysis. The scree plot and parallel analysis (see Figure 2) indicated that only four significant factors could be identified.
The final solution seemed to satisfactorily reflect four of the original seven subdimensions of the psychological ownership model (see Figure 1). The four factors of SAPOS, comprising 35 items, explained $57.37 \%$ of the total variance. The rotated pattern matrix for the 35 items of the SAPOS is displayed in Table 5. The four factors of the SAPOS were labelled Identity (16 items), responsibility (8 items), autonomy (6 items) and territoriality (5 items).

The results of the second-order factor analysis presented in Table 6 clearly indicated the existence of two distinctive dimensions, namely promotion- and prevention-orientated psychological ownership. Factors 1, 2 and 3 (identity, responsibility and autonomy) shared common variance and

TABLE 5: Rotated pattern matrix for the four-factor model.

\begin{tabular}{|c|c|c|c|c|c|}
\hline \multirow[t]{2}{*}{ Dimension } & \multirow[t]{2}{*}{ Item } & \multicolumn{4}{|c|}{ Factor } \\
\hline & & 1 & 2 & 3 & 4 \\
\hline \multicolumn{6}{|l|}{ Identity } \\
\hline Item 52 & I feel I have a strong bond with the organisation. & 0.919 & -0.011 & -0.071 & -0.011 \\
\hline Item 43 & I feel that this organisation is part of me. & 0.837 & -0.033 & 0.047 & -0.019 \\
\hline Item 51 & $\begin{array}{l}\text { I personally experience the successes and failures of the organisation as my successes and } \\
\text { failures. }\end{array}$ & 0.752 & -0.039 & -0.136 & 0.035 \\
\hline Item 31 & I feel that I belong in this organisation. & 0.742 & 0.009 & 0.175 & -0.066 \\
\hline Item 56 & $\begin{array}{l}\text { I feel that I have common interests with my organisation that are stronger than our } \\
\text { differences. }\end{array}$ & 0.714 & 0.056 & 0.060 & -0.157 \\
\hline Item 24 & I feel a strong linkage between me and my organisation. & 0.704 & -0.058 & 0.190 & -0.055 \\
\hline Item 34 & I feel 'at home' in this organisation. & 0.703 & 0.018 & -0.201 & -0.161 \\
\hline Item 66 & I feel that my personal values and those of the organisation are aligned. & 0.693 & 0.006 & 0.168 & -0.013 \\
\hline Item 27 & I feel as if this organisation is ' $\mathrm{MY}$ ' organisation. & 0.642 & -0.043 & 0.052 & 0.027 \\
\hline Item 40 & I feel totally comfortable being in the organisation. & 0.624 & 0.098 & 0.181 & -0.078 \\
\hline Item 55 & I feel secure in this organisation. & 0.613 & 0.003 & 0.231 & 0.003 \\
\hline Item 12 & I am proud to say that 'this is my organisation' to people that I meet. & 0.586 & -0.020 & 0.127 & -0.023 \\
\hline Item 49 & I feel I have a considerable emotional investment in my organisation. & 0.551 & 0.056 & 0.036 & 0.053 \\
\hline Item 6 & I feel the need to defend my organisation to outsiders when it is criticised. & 0.547 & -0.028 & 0.086 & 0.086 \\
\hline Item 61 & I feel the need to be seen as a member of the organisation. & 0.539 & 0.159 & 0.154 & 0.154 \\
\hline Item 9 & I feel the need to support my organisation's goals and policies. & 0.456 & 0.150 & 0.002 & 0.002 \\
\hline \multicolumn{6}{|c|}{ Responsibility } \\
\hline Item 47 & I accept full responsibility for my actions within the organisation. & 0.037 & 0.795 & 0.004 & 0.081 \\
\hline Item 54 & I accept ownership for the results of my decisions and actions. & 0.071 & 0.745 & -0.043 & -0.046 \\
\hline Item 63 & I feel personally responsible for the work I do in my organisation. & 0.069 & 0.706 & -0.071 & 0.002 \\
\hline Item 48 & I feel I should take the consequences of my work in the organisation. & 0.025 & 0.678 & 0.070 & 0.064 \\
\hline Item 62 & $\begin{array}{l}\text { If I cannot deliver on a task for whatever reason, I maintain the responsibility to find an } \\
\text { alternative resource or solution. }\end{array}$ & 0.017 & 0.653 & 0.008 & 0.008 \\
\hline Item 16 & I accept the consequences of my decisions in the organisation. & -0.057 & 0.632 & 0.096 & -0.006 \\
\hline Item 59 & $\begin{array}{l}\text { If the buck stops with me, I ensure that the task/complaint is resolved successfully every } \\
\text { time. }\end{array}$ & -0.032 & 0.630 & -0.057 & -0.081 \\
\hline Item 28 & I take responsibility for my decisions in the organisation. & -0.051 & 0.558 & 0.125 & -0.019 \\
\hline \multicolumn{6}{|l|}{ Autonomy } \\
\hline Item 23 & I take responsibility for my decisions in the organisation. & -0.028 & -0.018 & 0.775 & 0.040 \\
\hline Item 42 & I have considerable opportunity for independence and freedom in how I do my work. & 0.093 & 0.064 & 0.725 & 0.038 \\
\hline Item 29 & I am allowed to use my personal initiative and judgement in carrying out my work. & 0.108 & 0.008 & 0.705 & -0.036 \\
\hline Item 19 & I have the opportunity for independent thought and action. & 0.014 & 0.113 & 0.689 & -0.079 \\
\hline Item 38 & I have almost complete responsibility for deciding how and when the work is done. & 0.217 & -0.012 & 0.616 & 0.113 \\
\hline Item 11 & I have the freedom to schedule my work and determine how it is done. & 0.074 & 0.065 & 0.598 & 0.074 \\
\hline \multicolumn{6}{|c|}{ Territoriality } \\
\hline Item 39 & I feel the need to discourage others to invade my work space. & -0.063 & 0.028 & 0.032 & 0.792 \\
\hline Item 26 & I feel that people I work with should not invade my work environment. & -0.125 & -0.009 & 0.104 & 0.700 \\
\hline Item 35 & $\begin{array}{l}\text { I feel the need to protect my intellectual property from being used by others in the } \\
\text { organisation. }\end{array}$ & 0.035 & 0.021 & 0.014 & 0.678 \\
\hline Item 22 & I feel the need to protect my belongings from others in the organisation. & 0.031 & -0.004 & 0.045 & 0.584 \\
\hline Item 29 & I feel I need to defend my work environment from others in the organisation. & 0.077 & -0.052 & -0.081 & 0.470 \\
\hline
\end{tabular}




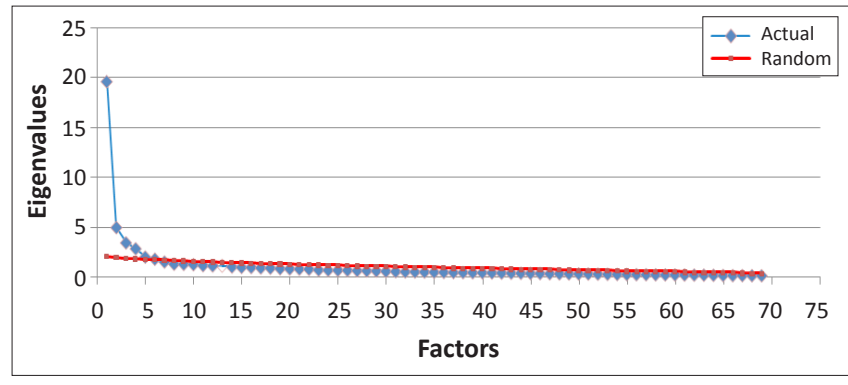

FIGURE 2: Scree plot of the actual data and the random data for 69 items.

TABLE 6: Rotated second-order factors from the matrix of factor correlations.

\begin{tabular}{lll}
\hline Factor & $\begin{array}{l}\text { Promotion-orientated } \\
\text { psychological ownership }\end{array}$ & $\begin{array}{l}\text { Prevention-orientated } \\
\text { psychological ownership }\end{array}$ \\
\hline Factor 1: Identity & $\mathbf{0 . 8 2 1}$ & 0.218 \\
Factor 2: Responsibility & $\mathbf{0 . 6 8 3}$ & -0.122 \\
Factor 3: Autonomy & $\mathbf{0 . 7 6 7}$ & -0.053 \\
Factor 4: Territoriality & -0.012 & $\mathbf{0 . 9 8 4}$ \\
\hline
\end{tabular}

contributed significantly ( $R=0.821, .683$ and 0.767 respectively) to a single overall dimension labelled promotion-orientated psychological ownership. factor 4 (territoriality) loaded to the second dimension $(R=0.984)$, labelled prevention-orientated psychological ownership.

\section{Confirmatory factor analysis}

Mardia's coefficient (397.433) and the normalised estimate of the coefficient (z-statistic) of 85.6875 indicated that the data was non-normally distributed and, therefore, the robust maximum-likelihood estimation with the Satorra-Bentler scaled chi-square was employed.

The Satorra-Bentler chi-square statistic of 951.772, based on 554 degrees of freedom $(p<0.0001)$, was significant and revealed a poor overall fit of the original, measured fourfactor SAPOS model. However, the chi-square statistic is very sensitive to sample size (Garson, 2002), with the result that a model with a large chi-square might still have a good fit if the fit indices are high. Therefore, the chi-square statistic was used with caution and other multiple-fit indices were applied to assess the model's goodness-of-fit. The model yielded a comparative fit index (CFI) value of 0.904 . This value is slightly greater than the required 0.90 but less than the level of 0.95 which has more recently been indicated as being desirable (Hu \& Bentler, 1999) in order to indicate a good model fit.

The root mean square error of approximation (RMSEA) value was estimated at 0.045 . This RMSEA value supports the belief that the model is a good fit because, according to Hair et al. (2006), RMSEA values between 0.05 and 0.08 are indicative of an acceptable fit. In a well-fitting model, the $90 \%$ confidence interval of the RMSEA should be between 0 and 0.08 . The $90 \%$ confidence interval of the RMSEA $(0.04,0.05)$ confirmed the acceptable fit of the four-factor measurement model to the data.

The model yielded a standardised root mean square residual (SRMR) value of .059. Considering the guideline of
Garson (2002) that SRMR values of less than 0.05 are widely considered to be a good fit and that values of below 0.08 are an adequate fit, this value illustrates a fairly good fit. Overall, the model appeared to fit the data reasonably well (Garson, 2002).

Figure 3 represents the path diagramme and fitted coefficients for the four-factor model. The 35-oneway arrows are indicative of regression coefficients that are indicative of the hypothesised effects of the observed variables, whereas the two-way arrows represent the covariance between the variables. The factor loadings indicate how well the observed variable explains each latent construct. Factor loadings exceeding 0.7 are recommended (Hair et al., 2006).

The latent constructs were allowed to correlate. The correlations in this model between the latent constructs identity and responsibility, and responsibility and autonomy, were relatively low, with values of 0.46 and 0.48 respectively. a moderate correlation with a value of 0.65 was found between identity and autonomy. as expected and as confirmed by the second-order factor analysis, the latent construct of territoriality (the preventive form of psychological ownership) showed either no (0.00) or extremely low negative correlations (-0.09 and -0.03) with the other more promotive latent constructs (Tabachnick \& Fidell, 2007).

\section{Descriptive statistics and internal consistency}

The results of the descriptive statistics of the SAPOS for the four factors are set out in Table 7. The data deviated from the normal distribution with a tendency towards negative skewness and leptokurtic distributions.

The coefficient alpha of Cronbach for each subscale was highly satisfactory, ranging between 0.78 and 0.94 . These results are displayed in Table 8.

\section{Criteria-related correlation}

Correlation between the constructs was determined by means of the Pearson correlation. Although the distribution is skewed, it was more useful to employ the Pearson correlation because of the relatively large sample size $(N=713)$. As opposed to the more promotion-orientated forms of psychological ownership, the prevention-orientated form of psychological ownership, namely feelings of territoriality, showed no relationship with the outcome variables. Promotive psychological ownership was related positively to affective commitment toward the organisation with an $r=0.642(p<0.01)$. A positive relationship was confirmed between job satisfaction and promotive psychological ownership $(r=0.536 ; p<0.01)$. Turnover intentions were related negatively to promotive psychological ownership with an $r=-0.376(p<0.01)$. The correlation results for all study variables are reported in Table 9.

\section{Discussion}

The purpose of this study was to develop an instrument for measuring psychological ownership in a South African 


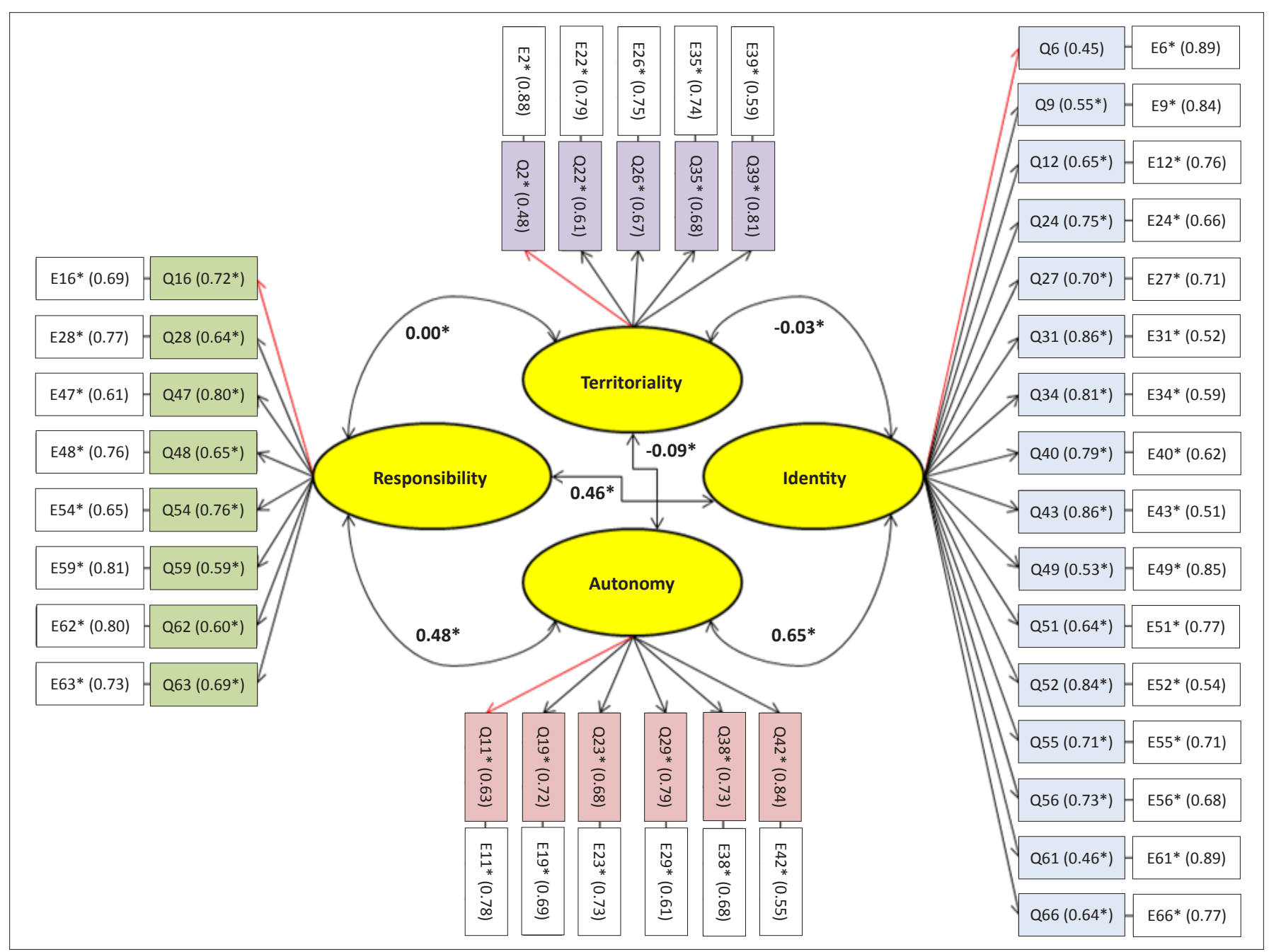

FIGURE 3: Standardised estimated parameters of the four-factor model.

TABLE 7: Descriptive statistics for the four scales of the South African Psychological Ownership Questionnaire.

\begin{tabular}{lllll}
\hline Descriptive statistic & Factor 1: Identity & Factor 2: Responsibility & Factor 3: Autonomy \\
\hline$N$ & 356 & 356 & 356 & Factor 4: Territoriality \\
M & 72.3258 & 41.3146 & 27.8258 & 356 \\
SE of mean & 0.69667 & 0.22004 & 0.27617 & 0.27821 \\
SD & 13.14472 & 4.15162 & 5.21082 & 5.24925 \\
Skewness & -1.126 & -0.930 & -1.189 & 0.134 \\
Skewness error & 0.129 & 0.129 & 0.129 & 129 \\
Kurtosis & 1.534 & 2.827 & 2.031 & -0.725 \\
Kurtosis error & 0.258 & 0.258 & 0.258 & 0.258 \\
\hline
\end{tabular}

$\mathrm{M}$, mean; SE, standard error; SD, standard deviation.

context since previous studies had not succeeded in compiling a comprehensive measurement instrument. Although the initial theoretical model of psychological ownership comprised six promotion-orientated dimensions, namely self-efficacy, self-identity, sense of belonging, accountability, autonomy and responsibility, as well as one preventionorientated dimension, namely territoriality, the results of the South African sample confirmed only three promotionorientated psychological ownership dimensions, namely identity, responsibility and autonomy and the one preventionorientated dimension, namely territoriality. The SAPOS thus comprised 35 items that tapped into the four dimensions of identity, responsibility, autonomy and territoriality.
Although 10 items had been included to capture the dimension of self-efficacy, none of these items survived the stages of scale development. The items either cross-loaded or loaded on dimensions that were theoretically inconsistent with the factor. Self-efficacy items should, therefore, be reviewed, because this aspect forms a central part of the psychological ownership concept. Self-efficacy is concerned with specific judgement of one's capability and competence (Sternberg, 2001), however, it seemed that the sample group did not interpret the relevant questions as such, but rather interpreted some of them as if they referred to responsibility. It needs to be noted that different sources of information influence self-efficacy, depending on a person's cultural values (Earley, 1994). 
TABLE 8: Internal consistency for the subscales of the South African Psychological Ownership Questionnaire.

\begin{tabular}{|c|c|c|}
\hline Variables & $\begin{array}{l}\text { Corrected item - total } \\
\text { correlation }\end{array}$ & $\begin{array}{l}\text { Cronbach's alpha if item } \\
\text { deleted }\end{array}$ \\
\hline \multicolumn{3}{|l|}{ Factor 1: Identity } \\
\hline Q6 SI & 0.497 & 0.940 \\
\hline Q9 SI & 0.494 & 0.939 \\
\hline Q12 SI & 0.636 & 0.936 \\
\hline Q24 SI & 0.757 & 0.933 \\
\hline Q27 B & 0.628 & 0.937 \\
\hline Q31 B & 0.795 & 0.932 \\
\hline Q34 B & 0.769 & 0.933 \\
\hline Q40 B & 0.714 & 0.932 \\
\hline Q43 B & 0.818 & 0.932 \\
\hline Q49 B & 0.579 & 0.938 \\
\hline Q51 SI & 0.633 & 0.937 \\
\hline Q52 B & 0.844 & 0.931 \\
\hline Q55 B & 0.699 & 0.935 \\
\hline Q56 SI & 0.724 & 0.934 \\
\hline Q61 SI & 0.507 & 0.939 \\
\hline Q66 SI & 0.763 & 0.933 \\
\hline Scale reliability: 0.939 & - & - \\
\hline \multicolumn{3}{|l|}{ Factor 2: Responsibility } \\
\hline Q16 Acc & 0.602 & 0.858 \\
\hline Q28 Acc & 0.523 & 0.866 \\
\hline Q47 R & 0.738 & 0.845 \\
\hline Q48 R & 0.634 & 0.855 \\
\hline Q54 R & 0.716 & 0.846 \\
\hline Q59 R & 0.567 & 0.863 \\
\hline Q62 R & 0.598 & 0.859 \\
\hline Q63 R & 0.664 & 0.852 \\
\hline Scale reliability: 0.871 & - & - \\
\hline \multicolumn{3}{|l|}{ Factor 3: Autonomy } \\
\hline Q11 Aut & 0.631 & 0.862 \\
\hline Q19 Aut & 0.654 & 0.857 \\
\hline Q23 Aut & 0.673 & 0.854 \\
\hline Q29 Aut & 0.681 & 0.853 \\
\hline Q38 Aut & 0.691 & 0.853 \\
\hline Q42 Aut & 0.764 & 0.838 \\
\hline Scale reliability: 0.874 & - & - \\
\hline \multicolumn{3}{|l|}{ Factor 4: Territoriality } \\
\hline Q2 T & 0.428 & 0.778 \\
\hline Q22 T & 0.552 & 0.734 \\
\hline Q26 T & 0.536 & 0.740 \\
\hline Q35 T & 0.599 & 0.718 \\
\hline Q39 T & 0.649 & 0.703 \\
\hline Scale reliability: 0.776 & - & - \\
\hline
\end{tabular}

$\mathrm{Q}$, question.

As far as the four-factor solution was concerned, 10 of the self-identity items and eight of the sense-of-belonging items loaded on one factor. The self-identity and sense-of-belonging constructs seemed to be very similar because, according to Lee (as cited in Edwards, 2005, p. 210), identification involves a sense of belongingness, which is supported by Ashforth and Mael (1989, p. 21) who refer to identification as 'the perception of oneness or belongingness'. Avey et al. (2009) argue that although the underlying principle of ownership might be manifested in both self-identity and belongingness, these two should remain distinct, yet related, constructs. However, the results of an exploratory factor analysis, based on the psychological ownership questionnaire (POQ) developed by Avey et al. (2009) and conducted on a South African sample comprising 145 health professional employees, also indicated that the self-identity and sense-of-belonging items loaded onto one factor (Alberts, 2012).

Ownership is frequently associated with a bundle of rights (Pierce et al., 2001). Most frequently associated with ownership are the right to information about the target of ownership and the right to have a voice in decisions that impact on the target. The expectation of information sharing and the permission to influence the direction of the target are consequences of the right to hold others accountable. The accountability dimension was not clearly distinguished.

According to Wood and Winston (2007), being 'responsible' involves liability to be called to account whereas being accountable has to do with the acceptance of responsibility and showing voluntary transparency and answerability. Wood and Winston (2007) point out that it is possible for someone to be responsible without being accountable, because responsibility might be assigned, enforced or even mistakenly applied to an individual or group by external forces. This might have been the reason why a number of accountability items loaded on the responsibility dimension.

The four-factor model comprising 35 items was subjected to confirmatory factor analysis. The CFI (0.904), RMSEA (0.045) and SRMR (0.059) values met the minimum recommended standards as set down by Garson (2002), Hu and Bentler (1999) and Hair et al. (2006), therefore indicating an acceptable fit.

The relationship between psychological ownership and other constructs was examined to develop a semantic network. As anticipated, and in accordance with empirical research findings by Avey et al. (2009), Mayhew et al. (2007) and O'Driscoll, Pierce and Coghlan (2006), promotion-orientated psychological ownership was related positively to affective commitment and job satisfaction. As expected, and as confirmed by Avey et al. (2009), turnover intentions were related negatively to promotion-orientated psychological ownership.

\section{Contribution of the study}

The key contribution of this study has been the development and testing of a multi-dimensional instrument for measuring psychological ownership that can be used in South African organisations. The results provided psychometric support for the SAPOS as a multi-dimensional measure of psychological ownership. Furthermore, the results showed that the unique emphasis of psychological ownership and the situation of having employees who felt like owners increased our understanding of and ability to predict employees' organisational commitment, satisfaction and intention to stay in the organisation. If a sense of psychological ownership for the organisation could be created amongst employees, especially those in skilled and professional positions, by addressing the factors as measured by the SAPOS, an organisation could become an enhanced workplace that 
TABLE 9: Relationships with psychological ownership.

\begin{tabular}{|c|c|c|c|c|c|c|c|c|c|}
\hline Relationship & & $\begin{array}{l}\text { Promotive } \\
\text { psychological } \\
\text { ownership }\end{array}$ & Identity & Responsibility & Autonomy & Territoriality & Commitment & Job satisfaction & $\begin{array}{l}\text { Turnover } \\
\text { intentions }\end{array}$ \\
\hline \multirow{3}{*}{$\begin{array}{l}\text { Promotive } \\
\text { psychological } \\
\text { ownership }\end{array}$} & Pearson correlation & 1 & - & - & - & - & - & - & - \\
\hline & Sig. (2-tailed) & - & - & - & - & - & - & - & - \\
\hline & $N$ & 713 & - & - & - & - & - & - & - \\
\hline \multirow[t]{2}{*}{ Identity } & Pearson correlation & $0.944 * *$ & 1 & - & - & - & - & - & - \\
\hline & $N$ & 713 & 713 & - & - & - & - & - & - \\
\hline \multirow[t]{3}{*}{ Responsibility } & Pearson correlation & $0.614^{* *}$ & $0.416 * *$ & 1 & - & - & - & - & - \\
\hline & Sig. (2-tailed) & 0.000 & 0.000 & - & - & - & - & - & - \\
\hline & $N$ & 713 & 713 & 713 & - & - & - & - & - \\
\hline \multirow[t]{3}{*}{ Autonomy } & Pearson correlation & $0.757^{* *}$ & $0.575^{* *}$ & $0.364 * *$ & 1 & - & - & - & - \\
\hline & Sig. (2-tailed) & 0.000 & 0.000 & 0.000 & - & - & - & - & - \\
\hline & $N$ & 713 & 713 & 713 & 713 & - & - & - & - \\
\hline \multirow{2}{*}{ Territoriality } & Sig. (2-tailed) & 0.759 & 0.286 & 0.417 & 0.375 & - & - & - & - \\
\hline & $N$ & 713 & 713 & 713 & 713 & 713 & - & - & - \\
\hline \multirow[t]{3}{*}{ Commitment } & Pearson correlation & $0.642 * *$ & $0.675^{* *}$ & $0.324 * *$ & $0.371^{* *}$ & -0.071 & 1 & - & - \\
\hline & Sig. (2-tailed) & 0.000 & 0.000 & 0.000 & 0.000 & 0.058 & - & - & - \\
\hline & $N$ & 713 & 713 & 713 & 713 & 713 & 713 & - & - \\
\hline \multirow[t]{3}{*}{ Job satisfaction } & Pearson correlation & $0.536^{* *}$ & $0.526 * *$ & $0.249 * *$ & $0.420 * *$ & $-0.147 * *$ & $0.467^{* *}$ & 1 & - \\
\hline & Sig. (2-tailed) & 0.000 & 0.000 & 0.000 & 0.000 & 0.000 & 0.000 & - & - \\
\hline & $N$ & 708 & 708 & 708 & 708 & 708 & 708 & 708 & - \\
\hline \multirow[t]{3}{*}{ Turnover intentions } & Pearson correlation & $-0.376 * *$ & $-0.412^{* *}$ & $-0.115^{* *}$ & $-0.236 * *$ & $0.156 * *$ & $-0.459 * *$ & $-0.475 * *$ & 1 \\
\hline & Sig. (2-tailed) & 0.000 & 0.000 & 0.002 & 0.000 & 0.000 & 0.000 & 0.000 & - \\
\hline & $N$ & 709 & 709 & 709 & 709 & 709 & 709 & 708 & 709 \\
\hline
\end{tabular}

**, Correlation is significant at the 0.01 level (2-tailed).

would be able to sustain performance and retain staff; and that would be of significant value to the organisation in these uncertain economic times.

\section{Limitations of the study and recommendations}

No study of this nature is without limitations, especially because psychological ownership is a complex phenomenon. Hair et al. (2006) recommend that if the sample size is large enough, the sample could be split randomly into two subsets, as was done in this study. However, Hinkin (1988) suggests that it is necessary to use several independent samples in scale development as a result of the fact that results of many multivariate techniques can be samplespecific. It is, therefore, suggested that although the sample was collected from professional and managerial employees in various South African organisations in both the private and public sectors, the instrument should be tested on another independent sample.

Although the sample size was adequate to conduct a factor analysis, this does not necessarily mean that the sample was representative of the general population. The sample comprised 418 White (60\%) and 284 Black (40\%) respondents, which included 24 mixed-race and 34 Indian respondents. Further research needs to be conducted amongst a broader spectrum of cultural participants, as this could have an influence on the way in which questions are interpreted. A sample more representative of the general South African population should be used in follow-up studies.

A cross-sectional design was applied and it was thus not possible to control for confounding variables. A qualitative dimension to the research might be valuable and could enhance knowledge on the key issues that might influence psychological ownership in a diverse multi-cultural environment.

Further studies should investigate the role that additional antecedents, such as locus of control and individualism, might play in explaining the underlying motives of psychological ownership.

It is recommended that the Rasch analysis, as opposed to the factor analysis, be used to further validate the instrument because, according to Waugh and Chapman, 2005), factor analysis does not always provide a conceptual linear assessment of the construct and might provide misleading evidence.

\section{Conclusion}

A four-dimensional, 35-item psychological ownership measurement instrument called the South African Psychological Ownership Questionnaire (SAPOS) was developed. Although the findings were encouraging, it should be borne in mind that scale validation is an ongoing process. Continued refinement of the SAPOS is thus suggested.

\section{Acknowledgements Competing interests}

The author declares that she has no personal or financial relationship(s) which might have inappropriately influenced her in the writing of this article. 


\section{References}

Alberts, C. (2012). Confirmatory factor analysis of the psychological ownership questionnaire for the South African context. Unpublished master's thesis, University of Pretoria, Pretoria, South Africa.

Amabile, T.M. (1983). The social psychology of creativity. New York: Springer-Verlag. http://dx.doi.org/10.1007/978-1-4612-5533-8

Ashforth, B.E., \& Mael, F. (1989). Social identity theory and the organization. Academy of Management Review, 14(1), 20-39. http://dx.doi.org/10.2307/258189, http:// dx.doi.org/10.5465/AMR.1989.4278999

Avey, J.B., Avolio, B.J., Crossley, C.D., \& Luthans, F. (2009). Psychological ownership: Theoretical extensions, measurement, and relation to work outcomes. Journal of Organizational Behavior, 30, 173-191. http://dx.doi.org/10.1002/job.583

Bandura, A. (1995). Self-efficacy in changing societies. New York: Cambridge University. http://dx.doi.org/10.1017/СВ09780511527692

Bentler, P.M. (2004). EQS 6.1 Structural equations program manual. Encino: California.

Bentler, P.M. (2007). On tests and indices for evaluating structural models. Personality and Individual Differences, 42(5), 825-829. http://dx.doi.org/10.1016/j. paid.2006.09.024

Brown, G., Lawrence, T.B., \& Robinson, S.L. (2005). Territoriality in organizations. Academy of Management Review, 30(3), 577-594. http://dx.doi.org/10.5465/ AMR.2005.17293710

Buchko, A.A. (1993). The effects of employee ownership on employee attitudes - an integrated causal model and path-analysis. Journal of Management Studies, 30(4), 633-657. http://dx.doi.org/10.1111/j.1467-6486.1993.tb00319.x

Cronbach, L.J., \& Meehl, P.E. (1955). Construct validity in psychological tests. Psychological Bulletin, 52(4), 281-302. http://dx.doi.org/10.1037/h0040957, PMid:13245896

De Beuckelaer, A., Lievens, F., \& Swinnen, G. (2007). Measurement equivalence in the conduct of a global organizational survey across countries in six cultural regions. Journal of Occupational and Organizational Psychology, 80(4), 575-600. http:// dx.doi.org/10.1348/096317907X173421, PMid:17535464

DeVellis, R. (2003). Scale development: theory and applications (2nd edn.). Thousand Oaks, CA: Sage. PMid:14558062

Dirks, K.T., Cummings, L.L., \& Pierce, J.L. (1996). Psychological ownership in organizations: conditions under which individuals promote and resist change. In R.W. Woodman, \& W.A. Pasmore (Eds.), Research in organizational change and development, Vol 9 (pp. 1-23). Greenwich, CT: JAI Press Inc.

Dittmar, H. (1992). The social psychology of material possessions: to have is to be. New York: Palgrave MacMillan. PMCid:PMC2547961

Earley, P.C. (1994). Self or group? Cultural effects of training on self-efficacy and performance. Administrative Science Quarterly, 39(1), 89-117. http://dx.doi. org/10.2307/2393495

Edwards, M.R. (2005). Organizational identification: a conceptual and operational review. International Journal of Management Reviews, 7(4), 207-230. http://dx.doi. org/10.1111/j.1468-2370.2005.00114.x

Furby, L. (1978). Possession in humans: An exploratory study of its meaning and motivation. Social Behaviour and Personality, 6(1), 49-65. http://dx.doi. org/10.2224/sbp.1978.6.1.49

Garson, G.D. (2002). PA765 Statnotes: an online textbook. Retrieved September 28 2013, from http://faculty.mdc.edu/mshakil/StatNotes\%20Online\%20Textbook\%20 2013, from http://faculty.
for\%20PA\%20765.htm

Hackman, J.R., \& Oldham, G.R. (1980). Work redesign. Reading, MA: Addison-Wesley. PMCid:PMC1282848

Hair, J.F. Jr, Black, W.C., Babin, B.J., Anderson, R.E., \& Tatham, R.L. (2006). Multivariate data analysis. (6th edn.). New Jersey: Pearson-Prentice Hall.

Harvey, R.J., Billings, R.S., \& Nilan, K.J. (1985). Confirmatory factor analysis of the Job Diagnostic Survey: good news and bad news. Journal of Applied Psychology, 70(3), Diagnostic Survey: good news and bad news. Journal of $A p p$
461-468. http://dx.doi.org/10.1037/0021-9010.70.3.461

Higgens, E.T. (1997). Beyond pleasure and pain. American Psychologist, 52(12), 12801300. http://dx.doi.org/10.1037/0003-066X.52.12.1280

Hinkin, T.R. (1998). A brief tutorial on the development of measures for use in questionnaires. Organizational Research Methods, 1(1), 104-121. http://dx.doi. org/10.1177/109442819800100106

Horn, J.L. (1965). A rationale and test for the number of factors in factor analysis. Psychometrika, 30(2), 179-185. http://dx.doi.org/10.1007/BF02289447, PMid:14306381

Hu, L.T., \& Bentler, P.M. (1999). Cutoff criteria for fit indexes in covariance structure analysis: Conventional criteria versus new alternatives. Structural Equation Modeling, 6(1), 1-55. http://dx.doi.org/10.1080/10705519909540118

Idaszak, J.R., Bottom, W.P., \& Drasgow, F. (1988). A test of the measurement equivalence of the Revised Job Diagnostic Survey: past problems and current solutions. Journal of Applied Psychology, 73(4), 647-656. http://dx.doi.org/10.1037/00219010.73 .4 .647

Krzystofiak, F., Cardy, R.L., \& Newman, J. (1988). Implicit personality and performance appraisal: The influence of trait inferences on evaluation of behavior. Journal of Applied Psychology, 73(3), 515-521. http://dx.doi.org/10.1037/0021-9010.73.3.515

Lawshe, C. (1975). A quantitative approach to content validity. Personnel Psychology, 28, 563-575. http://dx.doi.org/10.1111/j.1744-6570.1975.tb01393.x

Lerner, J.S., \& Tetlock, P.E. (1999). Accounting for the effects of accountability. Psychological Bulletin, 125(2), 255-275. http://dx.doi.org/10.1037/00332909.125.2.255, PMid:10087938

Luthans, F. (2002). The need for and meaning of positive behavior. Journal of Organizational Behavior, 23(6), 695-706. http://dx.doi.org/10.1002/job.165

Maré, Y. (2009). Exploratory structural equation modeling: Validating the OCP. Unpublished master's thesis, University of Pretoria, Pretoria, South Africa.
Mattes, R., \& Richmond, W. (2000). The brain drain: What do skilled South Africans think? In J. Crush (Ed.), Losing our minds: Skills migration and the South African brain drain, Migration Policy Series No. 18. (pp. 9-35). Cape Town: Idasa/Southern brain drain, Migration
Africa Migration Project.

Mayhew, M.G., Ashkanasy, N.M., Bramble, T., \& Gardner, J. (2007). A study of the antecedents and consequences of psychological ownership in organizationa settings. Journal of Social Psychology, 147(5), 477-500. http://dx.doi.org/10.3200/ SOCP.147.5.477-500, PMid:18225830

Meyer, J.P., \& Allen, N.J. (1991). A three-component conceptualization of organizational commitment. Human Resource Management Review, 1(1), 61-89. http://dx.doi. org/10.1016/1053-4822(91)90011-Z

O'Driscoll, M.P., \& Beehr, T. (1994). Supervisor behaviors, role stressors and uncertainty as predictors of personal outcomes for subordinates. Journal of Organizational Behavior, 15(2), 141-155. http://dx.doi.org/10.1002/job.4030150204

O'Driscoll, M.P., Pierce, J. L., \& Coghlan, A. (2006). The psychology of ownership: work environment structure, organizational commitment, and citizenship behaviors. Group and Organizational Management, 31(3), 388-416. http://dx.doi. org/10.1177/1059601104273066

Olckers, C., Buys, M.A., \& Grobler, S. (2010). Confirmatory factor analysis of the Multi-

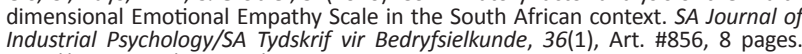
Industrial Psychology/SA Tydskrif vir Bedry
http://dx.doi.org/10.4102/sajip.v36i1.856

Olckers, C., Buys, M.A., \& Zeeman, A. (2007). The construct validity of Litwin \& Stringer's Organisational Climate Questionnaire in a South African Context. Paper presented at the 13th European Congress of Work and Organisational Psychology, Stockholm, Sweden. PMCid:PMC2186307

Olckers, C., \& Du Plessis, Y. (2012a). Psychological ownership: A managerial construct for talent retention and organisational effectiveness. African Journal of Business Management, 6(7), 2585-2596.

Olckers, C., \& Du Plessis, Y. (2012b). The role of psychological ownership in retaining talent: A systematic literature review. SA Journal of Human Resource Management/ SA Tydskrif vir Menslikehulpbronbestuur, 10(2), Art. \#415, 18 pages.

Peterson, C. (2000). The future of optimism. American Psychologist, 55(1), 44-55. http://dx.doi.org/10.1037/0003-066X.55.1.44, PMid:11392864

Pierce, J.L., Kostova, T., \& Dirks, K.T. (2001). Towards a theory of psychological ownership in organizations. Academy of Management Review, 26(2), 298-310. http://dx.doi org/10.2307/259124, http://dx.doi.org/10.5465/AMR.2001.4378028

Pierce, J.L., Kostova, T., \& Dirks, K.T. (2003). The state of psychological ownership: integrating and extending a century of research. Review of General Psychology, 7(1), 84-107. http://dx.doi.org/10.1037/1089-2680.7.1.84

Pierce, J.L., Rubenfeld, S.A., \& Morgan, S. (1991). Employee ownership: A conceptual model of process and effects. Academy of Management Review, 16(1), 121-144. http://dx.doi.org/10.2307/258609, http://dx.doi.org/10.5465/AMR.1991.4279000

Porteous, J.D. (1976). Home: The territorial core. Geographical Review, 66(4), 383-390. http://dx.doi.org/10.2307/213649

Rogers, L., \& Freundlich, F. (1998). Nothing measured, nothing gained. Employee Ownership Report, XVIII, No. 1. Oakland, CA: National Centre for Employee Ownership. Retrieved October 20, 2010 from http://www.ownershipassociates. com/nothingm.shtm

Rudmin, F.W., \& Berry, J.W. (1987). Semantics of ownership: A free-recall study of property. Psychological Record, 37(2), 257-268.

Ryan, R.M., \& Deci, E.L. (2006). Self-regulation and the problem of human autonomy: Does psychology need choice, self-determination, and will? Journal of Personality, 74(6),
1557-1585. http://dx.doi.org/10.1111/j.1467 6494.2006.00420.x, PMid:17083658

Seligman, M.E.P. (1999). The president's address. American Psychologist, 54(8), 559-562.

Snyder, C.R. (2000). Handbook of hope: theory, measures, and applications. San Diego: Academic Press.

SPSS 16.0 for Windows. [Computer software] (2008). Chicago: SPSS.

Sternberg, R.J. (2001). Psychology: In search of the human mind. Orlando, FL: Harcourt.

Tabachnick, B.G., \& Fidell, L.S. (2007). Using multivariate statistics. (5th edn.). Boston: Pearson Education. PMCid:PMC2724990

Utman, C.H. (1997). Performance effects of motivational state: a meta-analysis. Personality and Social Psychology Review, 1(2), 170-182. http://dx.doi.org/10.1207/ s15327957pspr0102_4, PMid:15647124

Van Dyne, L., \& Pierce, J.L. (2004). Psychological ownership and feelings of possession: Three field studies predicting employee attitudes and organizational citizenship
behaviors. Journal of Organizational Behavior, 25(4), 439-459. http://dx.doi. behaviors. Journal of

Vandewalle, D., Van Dyne, L., \& Kostova, T. (1995). Psychological ownership: an empirical examination of its consequences. Group and Organization Management, 20(2) 210-226. http://dx.doi.org/10.1177/1059601195202008

Wagner, S.H., Parker, C.P., \& Christianson, N.D. (2003). Employees that think and act like owners: Effects of ownership beliefs and behaviors on organizational effectiveness. Personnel Psychology, 56, 847-871. http://dx.doi.org/10.1111/j.1744-6570.2003. tb00242.x

Waugh, R.F., \& Chapman, E.S. (2005). An analysis of dimensionality using factor analysis (true-score theory) and Rasch measurement: what is the difference? Which method is better? Journal of Applied Measurement, 6(1), 80-99. PMid:15701946

Weil, S. (1952). The need for roots: Prelude to a declaration of duties toward mankind. London: Routledge \& Kegan Paul.

Welman, C., Kruger, F., \& Mitchell, B. (2005). Research Methodology. (3rd edn.). Oxford: Oxford University Press.

Wood, J.A., \& Winston, B.E. (2007). Development of three scales to measure leader accountability. Leadership \& Organization Development Journal, 28(2), 167-185. http://dx.doi.org/10.1108/01437730710726859

Worthington, R.L., \& Whittaker, T.A. (2006). Scale development research: a content analysis and recommendations for best practices. Counselling Psychologist, 34(6), 